\footnotetext{
${ }^{1}$ Department of Animal Production, Faculty of Agriculture, Zagazig University, Zagazig, Egypt

${ }^{2}$ Department of Animal Wealth, Institute of Efficient Productivity, Zagazig University, Egypt
}

\title{
Rabbits behavioural response to climatic and managerial conditions - a review
}

\begin{abstract}
The domestic rabbit is deprived of the protection of burrows and of a social hierarchy and live in a limited space which is a fraction of a metre of a hard sanitized space, removed from odours, markers and social interaction. Hot climate was the main cause for abnormal maternal and sexual behaviour. Exposure to high ambient temperature induces rabbits to try to balance their excessive heat load by using different means. The doe that was capable to produce 10 litters a year may give only 4 to 5 litters in hot climate Noise in rabitries causes adverse effects including nervous and behavioural abnormalities and can cause a startled response and traumatic injuries to limbs and back. Particularly, most concern about noise effects has traditionally focused on impairment of reproductive and maternal behaviours, although few controlled studies have been done to support the observations of animal caretakers that noise inhibits production. Moon phases are one of the main causes of abnormal sexual behaviour in females. Crowdness causes that rabbits become aggressive and bite one another during the first few days of nest sharing, while successive litters live together. Keeping rabbits singly in cages is not compatible with the demand of housing with respect to animal welfare, since the singly caged rabbit is exposed to natural external stimulus, has no social contact and has no conditions for suitable locomotion. This may be the reason in that caged rabbits show nervous behaviour and altered forms of movement and low relaxed resting-behaviour, that may be due to the narrowness of the cage and the wire floor. Social deprivation in rabbits interferes with the development of normal adult behaviours. However, among group-housed rabbits, survival at weaning was estimated to be $39 \%$ instead of $87 \%$ in individual cages. The behaviour and welfare of caged rabbit can be positively affected with repeated handling by familiar people. Minimal handling reduces timidity, particularly when performed during the first week of post-natal life. Higher growth rate and higher activity levels were recorded in rabbits handled daily for 10 minutes from 10 days to 10 weeks of age. Abuse and pushing the animals hard because of the method of production are cases in which the animals do not get optimal facilities necessary to fulfill their behavioural (ethological) needs.
\end{abstract}

Key Words: rabbit behaviour, climatic conditions, managerial conditions, human intervention, intensive production

\section{Zusammenfassung}

Titel der Arbeit: Verhaltensreaktionen bei Kaninchen unter dem Einfluss von Klima- und Bewirtschaftungsbedingungen - Eine Übersicht

Hauskaninchen leben abweichend von ihren Wildformen unter völlig veränderten Bedingungen. Dazu zählen u.a. ein begrenzter, von der Außenwelt isolierter Lebensraum, oder das Fehlen von Sozialkontakten bzw. das Leben ohne soziale Hierarchie. Besonders in heißen Klimazonen werden von der Norm abweichendes Fortpflanzungsergebnis, Sexualverhalten- oder andere Verhaltensweisen beobachtet. In vorliegender Literaturstudie werden ausgehend von natürlichen Lebensansprüchen des Kaninchens einzelne Einflussfaktoren auf Verhaltensweisen von Hauskaninchen erörtert. Dazu zählen klimatische Einflüsse wie Temperatur, Mondphasen, Tageslichtdauer in unterschiedlichen Klimazonen. Weitere Faktoren, welche an Hand zahlreicher Literaturquellen diskutiert werden, sind die Bewirtschaftungsbedingungen sowie die Betreuung durch den Menschen, Haltungssysteme und der Einfluss einer intensiven Produktion.

Schlüsselwörter: Kaninchenverhalten, Klimabedingungen, Bewirtschaftungsbedingungen, menschliche Betreuung, intensive Produktion 


\section{Introduction}

Optimal biological functioning of an organism occurs only when it lives in the appropriate surroundings. Under such conditions, the best overall functioning of the organisms assures and the maximum quality of life (well-being) is reached (SMIDT et al., 1995; MARAI and RASHWAN, 2003). However, the concept of the biological functioning must encompass the organism's overall capacity to interact with its surroundings to adjust to changes as they occur during its life (VALLE ZARATE, 1995).

All animals possess a range of behavioural expectations regarding their surroundings, in order to live physically and psychologically healthy. If the opportunity to exercise these expectations is restricted, the quality of their lives may be significantly reduced. Therefore, behaviour is considered as an animals action or reaction to a change in external or internal environment and may be innate or acquired and depends on both genetic characteristics and previous experience (HURNIK et al., 1985; FERRANTE et al., 1992a; HURNIK 1992; MANTEUFFEL, 2002).

An animals surroundings consist of numerous components of factors which can be defined generally as stimuli. An animal might be motivated to acquire or avoid certain stimuli, according to genetic predisposition or ontogenic experience.

Behavioural response can be defined as an observable interaction between the organism's motivational state and the perceived attributes (stimuli) of its environment.

Welfare is a condition of the animal itself and it is its state as regards to cope with its environment (BROOM, 1996; MANTEUFFEL and PUPPE, 1997) and under all conditions the animal should be healthy, thrifty and is allowed freedom to display normal patterns of behaviour. This necessitates providing freedom from thirst, hunger, malnutrition, discomfort, inadequate shelter and fear, prevention of pain, injury and distress and rapid diagnosis and treatment of injury and disease (MORISSE and MAURICE, 1994; SCHEIBE, 1997). Ill treatment is met through: cruelty that causes fear, injury, pain and/or distress, neglect either accidental or due to lack of knowledge that causes malnutrition, distress, diseases and maintaining animals in an unsuitable system which involves some specific deprivation that may cause abnormal behaviours called stereotypes (LAWRENCE and RUSHEN, 1993) and suffering. Abuse and pushing the animals hard because of the method of production are also cases in which the animals do not get optimal facilities necessary to fulfill their behavioural (ethological) needs (TUCHSCHERER and MANTEUFFEL, 2000).

The present article aimed to discuss the rabbits behavioural response to climatic and managerial conditions.

\section{Rabbits habitation}

Both wild and domestic rabbits, have enormous adaptability to exist in conditions ranging from the tropical to the arctic regions on exceptionally wide and varied diets. At the same time, rabbits can adapt to intensive husbandry systems in which they are kept with the aid of man (SANDFORD, 1992).

Changes in domestic rabbit behaviour than those of the wild one, illustrate the changes and potential stress caused by association with humans. At the same time, the reaction of wild rabbits often provides explanations for the problems of raising domestic rabbits and suggest ways of solving them (LEBAS et al., 1986). 
Wild rabbits burrow extensively in suitable soils, and their burrows may underlie hundreds and even thousands of square yards of pastoral land (JOHN and HARKNESS, 1988). In such conditions, a dominance hierarchy develops, mainly in males, while females seem to have smaller territory ability than males and share their home-range with other females (FERRANTE et al., 1992b). At the same time, the domestic rabbit is deprived of the protection of burrows and of a social hierarchy and live in a limited space which is a fraction of a metre of a hard sanitized space, removed from odours, markers and social interaction (KROHN et al.,1999).

\section{Climatic elements}

Among the climatic components that may impose influence on the animal are ambient temperature, humidity, air movement, radiation and photoperiod, of which the temperature is the most important.

Optimal climatic conditions for rabbits would be: air temperature $13^{\circ}$ to $20^{\circ} \mathrm{C}$ (average $15^{\circ} \mathrm{C}$ ), relative humidity 55 to $65 \%$ (average $60 \%$ ), wind velocity 5 to $18 \mathrm{~km} / \mathrm{h}$, ventilation capacity of at least $0.17 \mathrm{~m}^{3} /$ minute $(6 \mathrm{cfm})$ air flow per rabbit housed and a moderate level of sunshine.

Rabbit kits at birth are virtually hairless, with sealed eyelids and ear canals, little crawling ability and body mass ranging between 40 and 80 g (HARKNESS, 1988). They crouch, shiver and rock from side to side, as the temperature drops. After 30 minutes at $20.0^{\circ} \mathrm{C}$, the rectal temperature drops from $37.7^{\circ}$ to $32.7^{\circ} \mathrm{C}$ (CARDASIS and SINCLAIR, 1972). If the dam is present, the neonates seek warmth through maternal contact, apparently guided by thermo-receptors on the nose. This search is directed towards the mammary and occurs at nest temperatures of $32.7^{\circ} \mathrm{C}$ and below, while it may be absent at $36.1^{\circ} \mathrm{C}$ and above. Young without a doe placed in a low temperature (20.0-30. $0^{\circ} \mathrm{C}$ ), are grouped and curled up, although this grouping do not prevent chilling or moving in search of a warm area. However, SKRIVANOVA and MAROUNECK (1997) considered that $25^{\circ} \mathrm{C}$ is above the optimum temperature for young rabbits aged 30 days. FINZI et al. (1992) found that jumping movements disappeared completely at $32^{\circ} \mathrm{C}$ ambient temperature, while the small movements were reduced to bare minimum. In warm environment $\left(37.2-42.2^{\circ} \mathrm{C}\right)$, the young dispersed and assumed an extended position conducive to loose body heat. Bunnies of 5-10 weeks of age prefer cramming into the box to share warmth in cold weather, while on hot days in summer, they were all spread on their sides on the floor. A smooth PVC floor with holes should replace all wire flooring (McCROSKEY, 2000), whereas activity of rabbits was found to be higher on a litter floor than on plastic slats, regardless of the temperature (BESSEI et al., 1999).

Adult rabbits exposed to ambient temperatures below $10^{\circ} \mathrm{C}$, curl up to minimize their total body's surface area exposed and lower their ear temperature and the ear pinnae are folded to avoid internal surface from contact with air. At the same time, it drags the ear to bring it closer to the body. SEITZ et al. (1998) found relations between birth weight and mortality. At temperatures above $25-30^{\circ} \mathrm{C}$, rabbits stretch out to loose as much heat as possible by radiation and convection, step up their ear temperature, stretch ear pinnae and spread it far from the body to expose the surface to the surroundings to increase heat dissipation, since rabbits do not sweat. Above $35^{\circ} \mathrm{C}$, rabbits can no longer regulate their internal temperature and heat prostration sets in, 
while at $40^{\circ} \mathrm{C}$, considerable panting and salivation occurred (LEBAS et al., 1986). The average lethal ambient temperature is $42.8^{\circ} \mathrm{C}$. Particularly, feed consumption drops off, water consumption increases and heat production is reduced, during heat stress (MARAI and HABEEB,1994). BAGLIOICCA et al. (1987) reported that male fertility was impaired when ambient temperature was about $28^{\circ} \mathrm{C}$ and some individuals began to die at $35^{\circ} \mathrm{C}$. In females, VERGA (1992) indicated that hot climate was the main cause for abnormal maternal and sexual behaviour and postulated that the doe that was capable to produce 10 litters a year may give only 4 to 5 litters in hot climate. Exposure to high ambient temperature induces rabbits to try to balance the excessive heat load by using different means to dissipate, as much as possible, their latent heat. If such means fail, rabbits use strategies that include: depression in feed intake, efficiency and utilization, disturbances in water, protein, energy and mineral metabolism balances, enzymatic reactions, hormonal secretions and blood metabolites (JOHNSON, 1980; WITTROFF et al., 1988; HABEEB et al., 1992; KASA and THWAITES, 1992). Above $35{ }^{\circ} \mathrm{C}$, rabbits can no larger regulate their internal temperature and heat prostration sets in (LEBAS et al., 1986) as mentioned above. Particularly, in hot climate area, the most obvious limitation to rabbit production is the susceptibility to heat stress, which evokes a series of drastic changes in their biological functions that lead to impairment of production and reproduction (MARAI et al., 1991, 1999; FERNANDEZ et al., 1994). Such detrimental effects are accentuated during summer, and are reflected in limiting the breeding season of rabbits to be normally from September to May in sub-tropical regions, each year (MARAI et al., 1996 and 2002). Alleviation of heat stress can be carried out by the use of: Vitamin C (VERGA, 1992), offering cool water (MARAI et al., 2001), dietary supplementation with $2 \%$ protein above NRC (1977) level (AYYAT and MARAI, 1996) and supplementation with vegetable oil (MARAI et al., 1994).

At high levels of humidity, the event consequences mentioned above occur at lower temperatures than those recorded, due to that the feeling of warmth under hot ambient temperature increases with high relative humidity, although the temperature is interrelated with other climatic factors such as solar radiation, wind, photoperiod,...etc. Such relationship (between ambient temperature and humidity) induced LHPSI (1990) to propose a measurement of the level of severity of heat stress by using both factors and was termed Temperature-humidity index (THI). This parameter was modified by MARAI et al. (2001) for rabbits (as small animals).

Protection from cold winds may be required, but it must not be at the expense of adequate ventilation.

Length of daylight, seemed to affect most productive and reproductive traits of both sexes of rabbits. However, although rabbits are induced breeders, they have an annual cycle of reproduction which is shown in females by changes in conception rate, acceptance of the male, ovulation rate (MANCHISI et al., 1988) and in males by significant seasonal changes in testicular size (BOYD, 1986). SCHÜDDEMAGE et al. (2000) could prove the influence of light to higher sexual activity and semen parameters. Particularly, exposure of rabbits to long daylight often showed favourable effects on their reproductive traits and intermittent lighting may be a good alternative to the continuous lighting (LEBAS et al., 1986). However, in a study under the sub-tropical environment of Egypt, with its shining sun all the year, exposure of mature rabbits to the different light regimes showed adverse effects on most of the traits studied, when 
compared to the natural daylight, probably to that lamps radiation during application of the light regime technique increase the feeling of warmth and such perception is aggravated during the hot climatic conditions. The results also indicated that the natural daylight either during mild or hot conditions in the sub-tropical environment in Egypt, is suitable for the adult rabbit bucks (MARAI et al., Unpublished data). In does, it seemed that the $8 \mathrm{~h}$ daylight is suitable, during the hot conditions (MARAI et al., 2004). However, regarding the contradiction observed in the results mentioned in the literature, it is suggested to standardize the conditions under which the light regime experiments are carried out, since daylight criterion is interrelated with the other factors of climate as temperature, humidity, solar radiation, wind...etc., which differ from region to another and even within the same region.

The lunar cycle was found to be of potential significance in the evolution of natural cyclical phenomena of animals and plants. In animals, many semi-luner and full luner cycles have always been recorded in association with some particular reproductive events which occur only once or few times during the year (SUBRAMANIAM et al., 1991). In Czechoslovakia, HORÁK and POTUCEK (1978) found in 9650 ewes that the start of cycling of seasonal breeding was associated with the occurrence of the full moon. In India, SUBRAMANIAM et al. (1991) observed a relationship between phases of the moon and oestrous behaviour in cattle. Particularly, they found a strong positive correlation between new moon $(r=0.9426$; $\mathrm{P}<0.01)$, full moon $(\mathrm{r}=0.9584$; $\mathrm{P}<0.01)$ and number of cows presented for artificial insemination. However, the interactions between lunar phases and seasons were not significant, indicating that cows inseminated during lunar phases were not affected by the seasonal variations. In rabbits, VERGA (1992) noted that the moon phases (besides climate stress, bad feeding regime and change of the cage) are one of the main causes of abnormal sexual behaviour in females. However, the association between lunar phases and breeding behaviour, is not clearly understood.

Generally, when analyzing seasonal effects, temperature and light are considered in Europe, although temperature seems to be not directly involved (LEBAS et al., 1986). In tropical climates, temperature seems to be the dominant factor, but variations in length of daylight cannot be excluded. In sub-tropical climate (such as in Egypt), the ambient temperature, relative humidity and diurnal light seemed to be involved (HABEEB et al., 1993 and MARAI et al., 1996), although feasibility of the use of certain light regime in commercial rabbit production, is not clear (MARAI et al., 2004).

\section{Managerial elements}

In a comparative study, FINZI et al. (1992) found that more than $80 \%$ of the animals raised in cages and less than $40 \%$ in the partly underground housing system, laid in a stretched position during the hottest hours of the day. Rabbits raised in local huts showed an intermediate response with many of them resting in a normal position typical of not stressed animals. In case of partly underground housing, the proportion of the animals remaining inside the underground area during the middle of the day was above $75 \%$ of which $20 \%$ were active. Recently, FINZI et al. (2000) found that rabbits could really change the time spent in each of the sections of the shelter, according to their momentary ethological preference. The same authors added that the underground cell unit (Figure 1) appeared as a housing system suitable for animal welfare, allowing 
rabbits to satisfy and to modify their ethological needs inside a structurally articulated living environment.

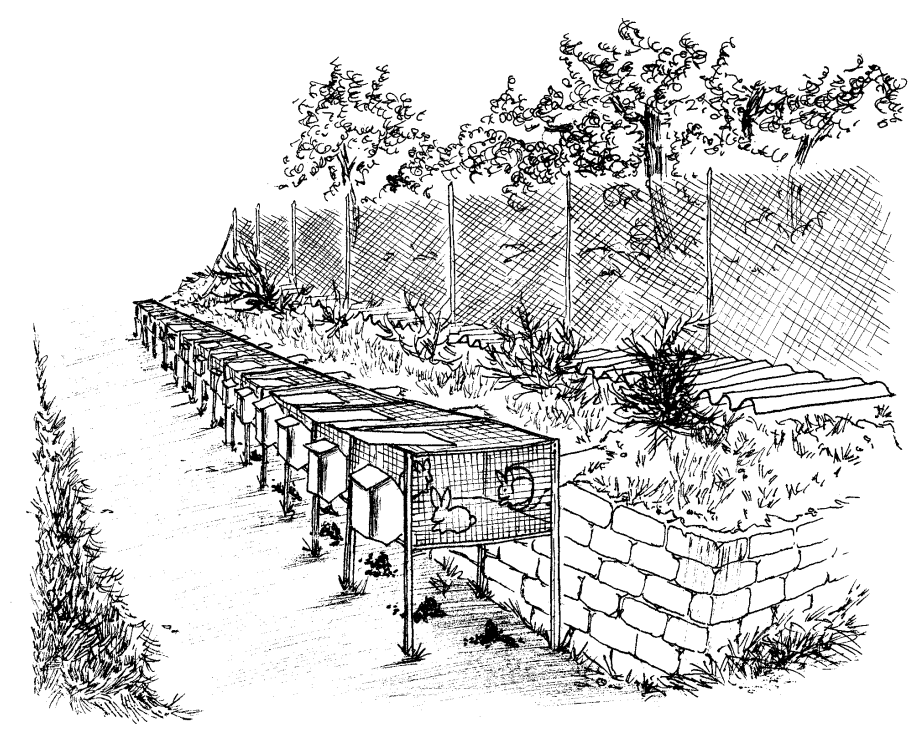

Fig. 1: General view of rabbit underground cell system (After FINZI, et al., 2000).

With regard to the noise, decibel threshold areas in the sensitive range of rabbits lies between zero and $20 \mathrm{~dB}$ sound pressure, which means a sensitive hearing. PETERSON (1980) recorded adverse effects of noise including nervous and behavioural abnormalities. Sudden noises in rabitries can cause a startled response and traumatic injuries to limbs and back. Similarly, the animals startle when they suddenly see people in the barn without any prior warning. Particularly, intensity rather than audio frequency is the most damaging aspect. To avoid startled response, one should talk to the rabbits when entering their habitation in order that rabbits be aware of his presence (CLOUGH and FASHAM, 1975). Particularly, most concern about noise effects has traditionally focused on impairment of reproductive and maternal behaviours, although few controlled studies have been done to support the observations of animal caretakers that noise inhibits production.

Rabbits exposed to varying light intensity, do not make an effort to avoid brighter lights. Under high light intensity, there was a tendency for higher weight gain (HARKNESS, 1988).

Crowdness causes that rabbits become aggressive and bite one another, during the first few days of nest sharing (WEBER and VAN DER WALT, 1975), while successive litters live together. Does in late pregnancy may kill the young when scratching to build a nest. However, some nest sharing may occur among rabbits of different ages and litters and stronger young survive at the expense of the weaker members.

In group-housed animals, mating commonly occurs within hours after parturition and pregnancy usually follows, although does often destroy weanlings when a new litter arrives. However, does killing or maiming young under group conditions do not occur when housed singly. In group-housed rabbits, disease is also more common (MÜLLER and BRUMMER, 1981).

Physiological parameters such as leucocytes evaluation, adrenal weight, lipids, lyosome enzymes, ascorbic acid and corticosterone levels, have been used as 
indicators in case of evaluating appropriation of housing and in welfare tests (WITEK et al., 1994, 1995; KLUSEK et al., 1995, 1997; VERGA, 2000).

\section{Raising systems}

The cage raising system represents an appropriate technology commonly adopted in tropical climates. Unfortunately, such system restricts the rabbits to protect themselves from the unfavourable environment and compels them to remain exposed without any defense to the noxious effect of heat (FINZI, 1988). In other words, the traditional breeding cage can produce stress in animals (DRESCHER, 1992), which is reflected on adaptive behaviour aspects (WIEPKEMA and KOOLHAS, 1993). Particularly, DRESCHER (1992) clarified that keeping rabbits singly in cages is not compatible with the demand of housing with respect to animal welfare, since the singly caged rabbit has no social contact to nonspecific necessary as natural external stimulus and has no conditions for suitable locomotion. This may be the reason in that caged rabbits show nervous behaviour, altered forms of movement and low relaxed restingbehaviour, because of the narrowness of the cage and the wire floor. In addition, social deprivation in rabbits interferes with the development of normal adult behaviours. DEBBIE and DAVID (1995) also found when studying the cyclical pattern of activities throughout the day and night of rabbits kept individually in standard laboratory cages $(49 \mathrm{~cm} \times 61 \mathrm{~cm} \times 48 \mathrm{~cm}$ ), signs of boredom behaviours and cage frustration (stereotypes), over the $24 \mathrm{~h}$ of the day. From another point of view, does raised singly spended more time nuzzling and took longer time to lordosis than those raised with litter mates. In addition, raising in cages, may produce abnormalities (DRESCHER, 1996), e.g. osteoporosis of the femur (LEHMANN, 1984), backbone distortions (WIESER, 1984), a high percentage of intestinal disorders (JACKSON, 1991) and other behavioural disorders (STAUFFACHER, 1992). McCROSKEY (2000) defined that cages smaller than $1 / 2 \mathrm{~m}^{2}$ eliminate the necessary locomotion that plays an important part in caecal motility. The type of floor may affect foot lesions in rabbits (MORISSE, 1999).

As an alternative to conventional cage housing, rabbits in group housing facility with plastic slatted floors (for fattening) showed better social interactions due to the increased opportunity for movement (PODBERSCEK et al., 1991 and REITER et al., 1993). However, such attempts to rear breeding animals in groups were bound to fail because of does aggressiveness towards the young, in addition to that one buck in six may be cannibalistic, especially when the animals living space was cramped. Additionally, in group rearing, disease is more common, and pre- and post-natal mortality may be distributed over the lactation period instead of within a few days of birth. Among group-housed rabbits, survival at weaning was estimated to be $39 \%$ instead of $87 \%$ in individual cages (HARKNESS, 1988).

Particularly, FERRANTE et al. (1992b) and CANALI et al. (2000) suggested that rabbits raising on ground floor meets better the specific characteristics, allowing them to react in a more adaptive way to potentially stressing stimuli. Rabbits in floor pens generally showed less abnormal behaviour than in those caged and rearing fattening rabbits in floor pens at high stocking density showed good growth performance.

Tables 1 and 2 show space requirements for young rabbits, fattening rabbits and breeders, according to UK Codes of Recommendations for the Welfare of livestock (1987) and German section of World Rabbit Science Association (1991), respectively. 
MAERTENS and DEGROOTE (1984) and LÖLIGER (1992) suggested that such requirements could be approximately as follows: doe and buck mass of $4.0-5.5 \mathrm{~kg}$ $0.30 \mathrm{~m}^{2}$ each, $>5.5 \mathrm{~kg} 0.40 \mathrm{~m}^{2}$, fattening pens of weanling $0.04 \mathrm{~m}^{2}$, fattening pens $3.3 \mathrm{~kg}$ live mass $0.08 \mathrm{~m}^{2}$ and nest box $0.10 \mathrm{~m}^{2}$. FERANTE et al. (1992b) also showed that young rabbits of 30 to 58 days of age could be kept in floor pens at high density $\left(0.085 \mathrm{~m}^{2}\right)$ on straw bedding. In the same respect, MORRISE and MAURICE (1994) suggested that stocking density of $40 \mathrm{~kg} / \mathrm{m}^{2}$ is the acceptable threshold in the terms of welfare in intensively reared caged rabbits.

Table $1 *$

Rabbits space requirements according to UK Codes of Recommendations for the Welfare of livestock (1987)

\begin{tabular}{lc}
\hline Housing system & Minimum space \\
\hline Cage rearing & $0.56 \mathrm{~m} 2$ total area \\
Does + pups up to 5 weeks of age & $0.74 \mathrm{~m} 2$ total area \\
Does + pups up to 8 weeks of age & $0.07 \mathrm{~m} 2 / \mathrm{subject}$ \\
Rabbits between 5 and 12 weeks of age & $0.18 \mathrm{~m} 2 / \mathrm{subject}$ \\
Rabbits after 12 weeks of age (multiple cages) & $0.56 \mathrm{~m} 2 / \mathrm{subject}$ \\
Breeders & \\
Group rearing & $0.75 \mathrm{~m} 2$ total area \\
Does + pups up to 5 weeks of age & $0.93 \mathrm{~m} 2$ total area \\
Does + pups up to 8 weeks of age & $0.09 \mathrm{~m} 2 / \mathrm{subject}$ \\
Rabbits between 5 and 12 weeks of age & $0.75 \mathrm{~m} 2 / \mathrm{subject}$ \\
Breeders &
\end{tabular}

Table 2*

Rabbits space requirements according to the German section of World Rabbit Science Association (1991)

\begin{tabular}{|c|c|c|}
\hline & Minimum space $(\mathrm{m} 2)$ & Height \\
\hline Breeders & 0.20 & 35 \\
\hline Up to $4 \mathrm{~kg}$ live weight & 0.30 & 40 \\
\hline Up to $5.5 \mathrm{~kg}$ live weight & 0.40 & 40 \\
\hline \multicolumn{3}{|c|}{ More than $5.5 \mathrm{~kg}$ live weight } \\
\hline \multicolumn{3}{|c|}{ Fattening rabbits } \\
\hline From weaning to 6 weeks & 0.04 & 35 \\
\hline Up to $3.3 \mathrm{~kg}$ live weight & 0.08 & 35 \\
\hline Pens & 0.12 & \\
\hline Nest & 0.10 & 30 \\
\hline
\end{tabular}

* (After VERGA, 2000, modified).

When using wire flooring minimum diameter should be 2.5-3.0 mm. PETERSON et al. (2000) postulated that plastic slats with $14 \mathrm{~mm}$ distance are considered acceptable with regard to hygiene and incidence of pododermatitis.

MARGARIT and FINZI (2000) suggested new units to take care of animal welfare equipped with two-floor cages (Figure 2 ). The cage was relatively simple and with a moderately higher cost that could ensure larger floor surface without reducing the number of does present in a building.

In the same respect, attempts were carried out to modify conventional cages and their environmental enrichment in order to improve the welfare of caged rabbits. BERTHELSEN and HANSEN (1999) reported that rabbits kept in cages where hay was available showed significantly less bar gnawing and excessive grooming, suggesting that rabbits were less stressed.

Generally, the studies on housing and stocking density showed that they have no consistent effects on food efficiency, gain, agnostic behaviour of weanlings (4-8 to 11 
weeks), disease or mortality (LUKEFAHR et al., 1980; MAERTENS and DEGROOTE, 1984, 1985; PRAWIRODIGDO et al., 1985).

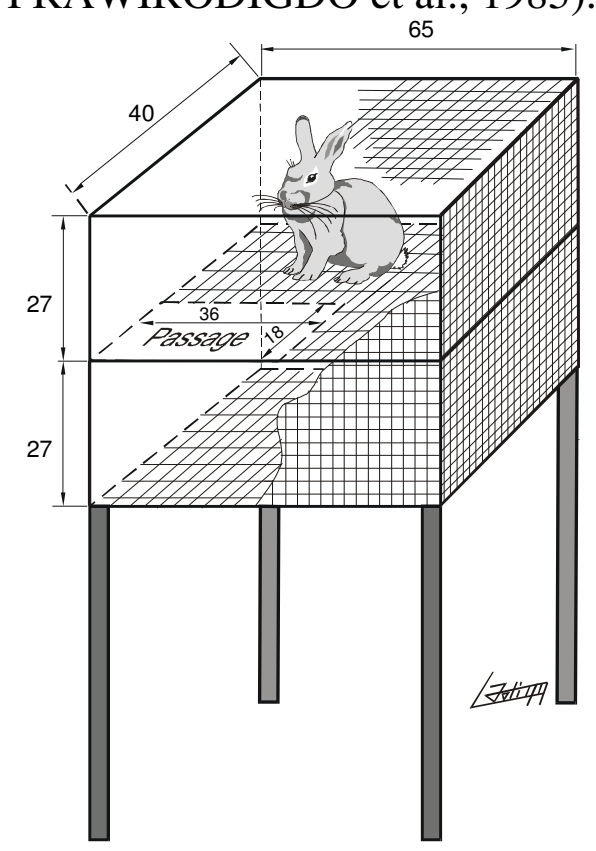

Fig. 2: Model of a two-floor cage for rabbit welfare (After MARGARIT and FINZI, 2000)

However, from the animal welfare point of view, it should be known that chronicle housing isolation of any gregarious animal is considered abnormal for that animal.

To alleviate boredom, empty tin cans or white PVC drain pipes of different sizes according to cage size and age of rabbits cut smoothly with no burrs can be used, but must be taken away at nesting time. Bleach or cresol could be used if needed for disinfections (McCROSKEY, 2000).

The human intervention

The behaviour and welfare of caged rabbit can be positively affected with repeated handling by familiar people (PODBERSCEK et al., 1991). Minimal handling reduces timidity, particularly when performed during the first week of post-natal life (HUDSON et al., 1996).

Rabbits were more active, awake, exploratory with enhanced sex activity when handled 3 minutes per day for periods 1-20 days of age than those isolated for the same period. More influence was shown from handling during the period of 11-20 days of age (WYLY et al., 1975). Particularly, JIEZIERSKI and KONECKA (1996) recorded higher growth rate and higher activity levels in rabbits handled daily for 10 minutes from 10 days to 10 weeks of age. DUPERRAY (1996) also found that rabbits handled from 17 to 20 days of life may reduce the mortality rate. Contrarily, young isolated for days 1-20 in separate nests showed lower growth rate and feed conversion efficiency (HARKNESS, 1988).

KERSTEN et al. (1989) found that early handling seems most effective in reducing emotionality if applied after the 10th day of life by placing the pups in a separate compartment of a closed box and returning them to the nest after 3 minutes.

In post weaned rabbits, a reduction in fearfulness towards humans has been shown following repeated approaching and handling (PODBERSCEK et al., 1991). 
Social deprivation in adult rabbit also interferes with the development of normal behaviour. In isolated litters, there was a trend towards lower mobility and does raised singly spent more time nuzzling males and took longer lordosis than did does raised with litter mates (HARKNESS, 1988).

\section{Impact of intensive production}

Optimal production can be achieved only by thrifty animals with kindling intervals of 32-42 days by the use of does that produce uniform litters with good mass. Such litters should be characterized by 8-9 kits as litter size and each weigh (mass) $60 \mathrm{~g}$ at birth, $320 \mathrm{~g}$ at least at three weeks and $1.8 \mathrm{~kg}$ at eight weeks of age (ROMMERS et al., 1999). However, maximizing animals productive and reproductive efficiencies can be realized through developing new managerial procedures. This necessitates better understanding of their behaviour by reading the sign language of animals, although it is needed not only to watch what the animal does, but how and when it occurs. Good welfare means thrifty animals and poor welfare results in abnormal behaviour that reflects negatively on productivity of the animal. In other words, some problems as abnormal behaviour become of definite concern to production and welfare.

In short, maintaining optimal productivity compatible with welfare demands, requires better understanding of rabbits natural behaviour.

Particularly, intensification of production may lessen welfare of the animal through pushing the animal hard by the different methods of production. In addition, the animal looses its freedom to display some of the normal patterns of behaviour, whereas developing some managerial procedures that alleviate such phenomena are useful.

But how much are the animal raisers in developing countries concerned with that mentioned above? Generally speaking, it should be known that although the typical meaning of animal welfare may be not well known to them, but they believe that maximal production cannot be obtained except by thrifty animals. Such belief is so deep that, sometimes, due to the animal raisers very limited financial resources, they prefer to fulfill their animal needs before their family's needs. Such phenomena prevail in the countryside due the great importance of the animal to their existence, and at the same time, to the close contact with their animals either in the fields (for the big animals) or in their houses, since the animals are normally housed in a part of the animal raisers lodgings.

\section{Conclusions}

Deviation in climatic and managerial conditions than optimum in rabbit production, may cause abnormal behavioural responses, in addition to inhibiting production.

\section{References}

AYYAT, M.S.; MARAI, I.F.M.:

Effect of summer heat stress on growth performance, some carcass traits and blood components of New Zealand White rabbits fed different protein - energy levels, under subtropical Egyptian conditions. $6^{\text {th }}$ World Rabbit Congr., France 2 (1996), 557-568

BAGLIOICCA, M.; CAMILLO, F.; PACI, G.:

Temperature e performance di conigli riproduttori. Rivista di Coniglicoltura 24 (1987), 10, 61-65 


\section{BERTHELSEN, H.; HANSEN, LT.:}

The effect of hay on the behaviour of caged rabbits (Oryctolagus cuniculus). Anim. Welfare 8 (1999) 2, 149-157

BESSEI, W.; RIVATELLI, D.; REITER, K.:

Experiments on temperature performance of rabbits (Abstract). World Rabbit Sci. 7 (1999) 3, 121

BOYD L.L.:

Photoperiod regulation of seasonal testicular regression in the wild European rabbits (Oryctolalgus

BROOM, D.M.:

Indicators of poor welfare. Br. Vet. J. 142 (1986), 524-526

CANALI, C.; DIVERIO, S.; BORANE, A.; DAL BOSCO, A.; BEGHELLI, V.:

The effect of transport and slaughter on rabbits reared in two different production systems. $7^{\text {th }}$ World Rabbit Congr., Valencia, Spain B (2000), 511-517

CARDASIS, C.A.; SINCLAIR, J.C.:

The effects of ambient temperature on the fasted newborn rabbit. 1. Survival times, weight loss, body temperature and oxygen consumption. Biol. of Neonates 21 (1972), 330-346

CLOUGH, G.; FASHAM, J.A.L.:

A silent fire alarm. Lab. Anim. 9 (1975), 193-196

DEBBIE, G. ; DAVID, B.M.:

Inventory of the behaviour of New Zealand White rabbits in laboratory cages. Appl. Anim. Behav. Sci. 45 (1995), 277- 292.

DRESCHER, B.:

Housing of rabbits to animal welfare. Appl. Rabbit Res. 15 (1992), 678-683

DRESCHER, B.:

Deformation of vertebral column in breeding rabbits. $6^{\text {th }}$ World Rabbit Congr., France (1996), 418-421

DUPERRAY, J.:

Que penser des relations manipulations-mortalite?. Cuniculture 23 (1996) 6, 263-267

FERNANDEZ, C.I.; BLAS, E.; CONCHA, C.:

Growth and some carcass traits of adult rabbits under high ambient temperature. World Rabbit Sci. 2 (1994), 147-151

FERRANTE, V.; VERGA, M.; CANALI, E.; MATTIELO, S.

Rabbit kept in cages and in floor pens. Reactions in the open field tests. Appl. Rabbit Res. 15 (1992a), 700-707

FERRANTE, V.; VERGA, M.; CANALI, E.; MATTIELLO, S.; CARENZI, C.:

Hybrid and New Zealand White rabbits kept in floor pens: space distribution and aggregations. Appl. FINZI, A.: Rabbit Res. 15 (1992b), 692-699

Problems of rabbit production in developing countries. $4^{\text {th }}$ World Rabbit Congress 1 (1988), 64-78

FINZI, A.; CIORBA, P.; MACCHIONI, P.:

Rabbit does behaviour in choosing living area in the underground cell system. $7^{\text {th }}$ World Rabbit Congr. Valencia, Spain B (2000), 525-530

FINZI, A.; VALENTINI, A.; FILIPPI BALESTRA, G.

Alimentary, excretory and motorial behaviour in rabbit at different ambient temperatures. Appl. Rabbit Res. 15 (1992), 732-738

HABEEB, A.A.; ABOUL-NAGA, A.I.; YOUSEF, H.M.:

Influence of exposure to high temperature on daily gain, feed efficiency and blood components of growing male Californian rabbits. Egyptian J. of Rabbit Sci. 3 (1993), 73-80

HABEEB, A.A.; MARAI, I.F.M.; KAMAL, T.H.:

Heat stress. In Farm Animals and the Environment, edited by C. Philips and D. Piggins. C.A.B. International. U.K. (1992), pp 27-47

HARKNESS, J.E.:

Rabbit behaviour as related to environmental stress. Appl. Rabbit Res. 11 (1988) 4, 227236

HORÁK, F.; POTUČEK, M.

The effect of the lunar phase on the sexual activity of the ewes. Sb. Vys. Šk. zeméd. Brne 23 (1978), 743749

HUDSON, R.; SCHAAL, B.; BILKO, A.; ALTBACKER, V.:

Just three minutes a day: The behaviour of young rabbits viewed in the context of limited maternal care. 6th World Rabbit Congr. France 2 (1996), 395-403

HURNIK, J.F.:

Behaviour. In Farm Animals and the Environment, edited by C. Phillips and D. Piggens. C.A.B. International. (1992), pp 235-244

HURNIK, J.F.; WEBSTER, A.B.; SIEGEL,, P.B.: 
Dictionary of Farm Animals Behaviour. Univ. of Guelph, Guelph, Canada. 1985

JACKSON, G.:

Intestinal stasis and rupture in rabbits. Vet. Records 129 (1991), 287-289

JIEZIERSKI ,T.A.; KONECKA, A.M.:

Handling and rearing results in young rabbits. Appl. Anim. Behav. Sci. 46 (1996), 243-250

JOHN, E.; HARKNESS, D.V.M.:

Rabbit behaviour as related to environmental stress. Appl. Rabbit Res. 11 (1988) 3, 227-236

JOHNSON, H.D.:

Environmental management of cattle to minimize the stress of climatic change. International Biometeorology 24 (1980), 14

KASA, I.W.; THWAITES, C.J.:

Semen quality in bucks exposed to $34^{\circ} \mathrm{C}$ for 8 hours on either 1 or 5 days. Appl.. Rabbit Res. 15 (1992), 560-568

KERSTEN, A.M.P.; MEIJSSER, F.M.; METZ, J.H.M.:

Effect of early handling on later open-field behaviour of rabbits. Appl. Anim. Behav. Sci. 24 (1989), 157167

KLUSEK,J.; KOLATAJ, A.; SWIDERSKA-KOLACZ, G.; RAFAY, J.:

The level of some lipids in the organs of rabbits during different ontogenesis periods. Arch. Tierz., Dummerstorf 40 (1997), 477-482

KLUSEK, J.; RAFAY, J.; SWIDERSKA-KOLACZ, G.; KOLATAJ, A.:

Influence of displacement stress on concentration of some lipids in rabbit organs. Arch. Tierz., Dummerstorf 38 (1995), 673-677

KROHN, TC.; RITSKES-HOITINGA, J.; SVENDSEN, P.:

The effects of feeding and housing on the behaviour of the laboratory rabbit. Lab. Anim. 33 (1999) 2, 101-107

LAWRENCE A.B.; RUSHEN J.:

Stereotypic Animal Behaviour. Fundamentals and Applications to Welfare. CAB International. 1993.

LEBAS, F.; COUDERT, P.; ROUVIER, R.; ROCHAMBEAU, H.DE.:

The Rabbit Husbandry, Health and Production. FAO Anim. Prod. and Health Series, Rome. 1986.

LEHMANN, M.:

Beurteilung der Tiergerechtheit handelsüblicher Batteriekäfige für Mastkaninchen. Report Swiss Federal Veterinary Office, Bern, Switzerland. 1984

LOLIGER, H.C.:

Consideration of animal protection and welfare in domestic rabbit housing and management: Necessity of world wide harmonization for animal welfare regulations in domestic rabbit housing and production.

LPHSI: Appl. Rabbit Res. 15 (1992) B, 684-691

Livestock and Poultry Heat Stress Indices, Agriculture Engineering Technology Guide. Clemson University, Clemson. Sc (1990), 29634. USA

LUKEFAHR, S.D.; CAVENY, D.D.; CHEEKE, P.R.; PATTON, N.M.:

Rearing rabbits in large cages. Appl. Rabbit Res. 3 (1980), 20-21

MAERTENS, L.; DeGROOTE, G.:

Influence of the number of fryer rabbits per cage on their performance. Appl. Rabbit Res. 7 (1984) 4, 151-155

MAERTENS, L.; DEGROOTE, G.:

L'influence de la densite d'occupation sur les resultats d'engraissement de lapins de chair. Revue de L'Agriculture 38 (1985), 463-471

MANCHISI, A.; GMBACORTA, M.; TOTEDA, C.; MARTEMUCCI, G.:

The effect of age and nutritional level on the ovulatory response of rabbits to GnRH, PMSG and PMSG+HCG. Anim. Breed. Abs. 56 (1988), 5225

MANTEUFFEL, G.:

Central nervous regulation of the hypothalamic-pituitary-adrenal axis and its impact on fertility, immunity, metabolism and animal welfare - a review. Arch. Tierz., Dummerstorf 45 (2002) 6, 575-595

MANTEUFFEL, G.; PUPPE, B.:

Is it possible to judge the subjective perception of internal state in animals. A critical analysis from a scientific point of view (German language). Arch. Tierz., Dummerstorf 40 (1997), 109-121

MARAI, I.F.M.; ABD EL-SAMEE, A.M.; EL-GAFARRY, M.N.:

Criteria of response and adaptation to high temperature for reproductive and growth traits in rabbits. Options Mediterraneennes, 17 (1991) A, 127-134

MARAI, I.F.M.; AYYAT, M.S.; ABDEL-MONEM, U.M.: 
Growth performance and reproductive traits at first parity of New Zealand White female rabbits as affected by heat stress and its alleviation, under Egyptian conditions. Tropical Anim. Health and Prod. 33 (2001), 451-462

MARAI, I.F.M.; AYYAT, M.S.; GABR, H.A.; ABD EL-MONEM, U.M.:

Effect of summer heat stress and its amelioration on production performance of New Zealand White adult female and male rabbits, under Egyptian conditions. $6^{\text {th }}$ World Rabbits Congr., Toulouse, France 2 (1996), 197-208

MARAI, I.F.M.; AYYAT, M.S.; GABR, H.A.; ABD EL-MONEM, U.M.:

Growth performance, some blood metabolites and carcass traits of New Zealand White broiler male rabbits as affected by heat stress and its alleviation, under Egyptian conditions. Cahiers Options Mediterraneennes 41 (1999), 35-42

MARAI, I.F.M.; EL-MASRY, K.A.; NASR, A.J.:

Heat stress and its amelioration with nutritional, buffering, hormonal and physical techniques for New Zealand White rabbits maintained under hot summer conditions of Egypt. Options Mediterraneennes, Serie Seminaires 8 (1994), Supplement: 475-487

MARAI, I.F.M.; HABEEB, B. A.:

Thermoregulation in rabbits. $1^{\text {st }}$ Conf. on Rabbit Prod. in Hot Climate, Cairo (1994), 33-41

MARA, I.F.M.; HABEEB, B. A.; GAD, A.E.:

Rabbits' productive, reproductive and physiological performance traits as affected by heat stress. A Review. Livest. Prod. Sci. 78 (2002), 71-90

MARA, I.F.M.; HABEEB, B. A.; GAD, A.E.:

Reproductive traits of female rabbits as affected bt heat stress and lighting regime under subtropical conditions of Egypt. Anim. Sci. 78 (2004), 119-127

MARAI, I.F.M.; RASHWAN, A.A.

Rabbit behaviour under modern commercial production conditions- a review. Arch. Tierz., Dummerstorf 46 (2003) 4, 357-376

MARGARIT, R.; FINZI, A.:

Setting of feeders, waterers and nest-boxes in two-floor cages for animal welfare. $7^{\text {th }}$ World Rabbit Congr. Valencia, Spain B (2000), 553-558

McCROSKEY, R.A.:

Behaviour of the rabbit. (A Review). Pan-Am. Rabbit Sci. Newsletter 5 (2000), 18-31

MORISSE, J.P.:

La protezione animale, come e perché. Rivista di Coniglicoltura 6 (1999), 9-14

MORISSE, J.P.; MAURICE, R.:

Welfare and the intensive production of rabbits. Revue - Office international des épizooties 13 (1994), $143-152$

MÜLLER, H.A; BRUMMER, H.:

Untersuchungen über Fortpflanzungsverhalten und Fertilität des Hauskaninchens in Einzel- und in Gruppenhaltung. Tierãrztl Umschau 36 (1981), 763-767

NRC.:

National Research Council. Nutrient Requirements of Domestic Animals. Nutrient Requirements of Rabbits. Second Revised Edition, National Acadamy of Sci., Washington, D.C., USA. 1977.

PETERSON, E. A.:

Noise and laboratory animals. Lab. Anim. Sci. 30 (1980), 422-439

PETERSEN, J.; SCHLENDER-BOBBIS, I.; MENNICKEN, L.:

Evaluation of optimal slat distance in slatted floor for rabbits using behavioural studies. $7^{\text {th }}$ World Rabbit Congr., Valencia, Spain B (2000), 559-565

PODBERSCEK, A.L.; BLACKSHAW, J.K.; BEATTIE, A.W.:

The behaviour of group penned and individually caged laboratory rabbits. Appl. Anim. Behav. Sci. 28 (1991), 353-373

PRAWIRODIGDO, S.; RAHARJO, Y.C.; CHEEKE, P.R.; PATTON, N.M.:

Effect of cage density on the performance of growing rabbit. Appl. Rabbit Res. 7 (1985), 151-155

REITER, J.; NICHELMANN, M.; WIERENGA, HK.; BRAUN, S.:

Housing systems for fattening and breeding rabbit with respect to animal behaviour. International Congr. on Appl. Ethol. Berlin (1993), 421-422

ROMMERS, J.M.; KEMP, B.; MEIJERHOF, R.; NOORDHUIZEN, J.P.T.M.

Rearing management of rabbit does: A review. World Rabbit Sci. 7 (1999), 125-138

SANDFORD, J.C.

Notes on the history of the rabbit. Appl. Rabbit Res. 15 (1992), 1-28

SCHEIBE, K. M.:

Animal welfare and animal behaviour - an ethological perspective (German language). Arch. Tierz., Dummerstorf 40 (1997), 381-398 
SCHÜDDEMAGE, M.; HOY, ST.; LANGE, K.:

Influence of artificial and natural light on behaviour during collection of semen and on spermatological parameters in rabbit bucks. (German language) Arch. Tierz., Dummerstorf 43 (2000) 4, 351-362

SEITZ, K.; HOY, ST.; LANGE, K.:

Influence of birth weight on mortality and life weight development in rabbits (German language). Arch. Tierz., Dummerstorf 41 (1998) 397-405

SKRIVANOVA, V.; MAROUNEK, $\mathrm{H}$.

Effect of ascorbic acid on performance, mortality, digestibility of nutrients and quality of meat of rabbits housed at $25^{\circ} \mathrm{C}$. Arch. Tierz., Dummerstorf 40 (1997) 2, 153-157

SMIDT, D.; SCHLICHTING, M. C.; LADEWIG, J.; STEINHARDT, M.:

Ethological and ethophysiological research for farm animals. (German language). Arch. Tierz., Dummerstorf 38 (1995), 7-19

STAUFFACHER, M.:

Group housing and enrichment cages for breeding, fattening and laboratory rabbits. Anim. Welfare 1 (1992), 105-125

SUBRAMANIAM, A.; DEVARAJAN, N.; VELAYUTHAM, N.; MOHANAN, M.:

Effect of lunar phases on variability of inseminations in cattle. Aust. Vet. J. 68 (1991) 2, 71-72

TUCHSCHERER, M.; MANTEUFFEL, G.:

The effect of psycho stress on the immune system. another reason for pursing animal welfare (review). (German language) Arch. Tierz., Dummerstorf 43 (2000) 6, 547-560

VALLE ZARATE, A.:

Breeding strategies for marginal regions in the tropics and subtropics (German language) Arch. Tierz., Dummerstorf 38 (1995), 461-478

VERGA, M.

Some characteristics of Rabbit behaviour and their relationship with husbandry systems. Appl. Rabbit Res. 15 (1992), 55-63

VERGA, M.:

Intensive rabbit breeding and welfare: development of research, trends and applications. $7^{\text {th }}$ World Rabbit Congr. (2000), B: 491-509

WEBER, H.W.; VAN DER WALT, J.J.:

Cardiomyopathy in crowded rabbits. Recent Advanced. Studied Cardiac Struct Metab. 6 (1975), 471-477

WIEPKEMA, P.R.; KOOHTODLAS, J.M.:

Stress and animal welfare. Anim. Welfare 2 (1993), 195-218

WIESER, R.V.:

Zur Tiergerechtheit handelsüblicher Batteriekäfige für Hauskaninchen Zibben. Report Swiss Federal Vet. Office, Bern, Switzerland. 1984

WITEK, B.; KOLATAJ, A.; KROL, T.:

Adaptive changes in the glucose level and activity of some lysosome enzymes in the plasma of starved rabbits. Arch. Tierz., Dummerstorf 38 (1995), 341-345

WITEK, B.; KOLATAJ, A.; RAFAY, J.:

The activity of lyosome enzymes in rabbits during the process of adaptation to stress. Arch. Tierz., Dummerstorf 37 (1994), 555-566

WITTROFF, E.K.; HEIRD, C.E.; RAKES, J.M.; JOHNSON, Z.B.:

Growth and reproduction of nutrient restricted rabbits in a heat stressed environment. Appl. Rabbit Res. 11 (1988), 92-87

WYLY, M.V.; DENENBERG, V.H.; DESANTIS, D., BURNS, J.K.; ZARROW, M.X.:

Handling rabbits in infancy: in search of a critical period. Develop. Psychobiology 8 (1975), 179-186

Received: 2003-04-10

Accepted: 2004-08-05

Authors' addresses

Prof. IBRAHIM FAYEZ M. MARAI

Department of Animal Production, Faculty of Agriculture, Zagazig University, Zagazig, Egypt

ALI A. RASHWAN

Department of Animal Wealth, Institute of Efficient Productivity, Zagazig University, Egypt 